\title{
Winter presence of adult male palmate newts (Lissotriton helveticus) in a pond in Scotland
}

\author{
GRANT WALKER ${ }^{1 *}$, BRADLEY FAIRCLOUGH ${ }^{2}$ \& ERIK PATERSON ${ }^{3}$ \\ ${ }^{1}$ Institute of Biodiversity Animal Health and Comparative Medicine, Graham Kerr Building University of Glasgow, Glasgow, \\ G12 8QQ, UK \\ ${ }^{2}$ University of Leeds, Leeds, UK \\ ${ }^{3} 205$ Telford Road, East Kilbride, G75 ODG, UK \\ *Corresponding author e-mail: grantwalkergw@gmail.com
}

\section{INTRODUCTION}

$T^{\mathrm{h}}$ he three species of newt that are native to Britain, palmate (Lissotriton helveticus), smooth (Lissotriton vulgaris) and great crested (Triturus cristatus), are also found throughout the temperate latitudes of western and central Europe (Mclnerny \& Minting, 2016). Across this region, newt species are subject to wide seasonal air temperature variations which result in a phenological pattern characterised by adult migration from terrestrial over-wintering refugia to spring breeding ponds; and subsequent post-breeding migration back to over-wintering refugia (Griffiths, 1984; Verrell \& Halliday, 1985). The specific cue that signals newts to commence the breeding migration is generally considered to be an increase in night-time air temperature above $4^{\circ} \mathrm{C}$ to $5^{\circ} \mathrm{C}$ following successive days of a stable temperature just below this level (Verrell \& Halliday, 1985; Langton et al., 2001; English Nature, 2001; Dervo et al., 2016); additionally, once in breeding ponds newts are generally considered to be inactive at air temperatures below $5^{\circ} \mathrm{C}$ or, potentially, following cold nights.

It is well documented that newt larvae, those individuals that have not fully metamorphosed, may remain in ponds through the winter months, before completing metamorphosis the following year (van Gelder, 1973; Griffiths, 1997; McNeill \& Downie, 2017). However, contrary to the established pattern, there are also reports of adult newts remaining in ponds during non-breeding months although these are much rarer. Dodd \& Callan (1955) reported that the majority of a cohort of male palmate newts over-wintered in a pond in Fife, Scotland; while Edgar \& Bird (2006) report that a small proportion of individuals may hibernate in the water. Notwithstanding, records of both adult over-wintering behaviour and of surveys from the postbreeding winter months generally appear in the literature much less frequently. Hence it remains to be seen whether the occurrence of adult newts overwintering in ponds is rare, undetected or under-reported.

\section{MATERIALS AND METHODS}

Surveys ( $n=14)$ were undertaken July 2016-April 2017 at a pond in Pumpherston, West Lothian, Scotland (NT 06647
70272). The pond is ovate in shape, with a $78 \mathrm{~m}$ perimeter and an area of $307 \mathrm{~m}^{2}$, as defined by terrestrial vegetation; and $0.4 \mathrm{~m}$ at the deepest point. Newt populations at the pond have been documented previously (Jehle et al., 2013).

Environmental parameters were measured at the pond edge immediately prior to commencing a survey. Ambient air temperature $\left(A^{t}\right)$ at $1.5 \mathrm{~m}$ above ground level was measured using a Hyelec PeakMeter MS6508 digital thermometer $\left( \pm 0.5^{\circ} \mathrm{C}\right)$ exposed to the air for $>60 \mathrm{~s}$ until the reading value had stabilised. Water temperature $\left(\mathrm{W}^{\mathrm{t}}\right)$ at a depth of c. 50 $\mathrm{mm}$ was measured $0.5 \mathrm{~m}$ from the pond edge of waterline using a TPI digital pocket thermometer $\left( \pm 1^{\circ} \mathrm{C}\right)$ and the stabilised temperature recorded. Equipment was calibrated at the University of Glasgow.

Newts were counted 30 minutes after sunset following a standard method described by Griffiths et al., (1996). Torching was preferred to bottle trapping as the latter should only be used when the night-time air temperature is $>5^{\circ} \mathrm{C}$ (English Nature, 2001) and surveys were targeting colder, winter months. A 1 million candlepower Clulite Clubman CB3 LED spotlight was used to illuminate all areas of water which could be accessed (>90\%) along the pond perimeter $(78 \mathrm{~m})$. The surveyor walked the same route and direction around the pond each time. Newt species, life-stage (adult/ juvenile/larvae) and sex (male/female) were classed where defining characteristics were observed (ARG UK, 2014), for example dark, webbed hind feet and tail filament in breeding adult male palmate, or recorded as 'unidentified'. Non-adult, juvenile newts are defined as individuals who are postmetamorphosed. Individuals that were not great crested newts but which could not be identified to gender level, were recorded as 'unsexed small newt' being palmate or smooth females, or males lacking secondary sexual characteristics. Newt classification was led by the same competent surveyor (author EP), holder of a Scottish Natural Heritage issued great crested newt survey licence, to control for recorder variability.

\section{RESULTS}

Palmate, smooth and great crested newts were recorded during pond surveys (Table 1 ). An adult newt of at least one species was present during every survey; juveniles were 
Table 1. Environmental parameters $\left(A^{t}=\right.$ air temperature, $W^{t}=$ water temperature $)$ and newt counts $(G C N=$ great crested newt, $P=$ palmate, $\mathrm{S}=$ smooth, $\hat{\delta}=$ adult male, $\rho=$ adult female, $\mathrm{J}=$ juvenile, $\mathrm{L}=$ larvae, Unsexed small newt = palmate or smooth females, or males without secondary sexual characteristics) for $n=14$ surveys

\begin{tabular}{|c|c|c|c|c|c|c|c|c|c|c|}
\hline \multirow[b]{2}{*}{ Date } & \multirow[b]{2}{*}{$A^{t}$} & \multirow[b]{2}{*}{$\mathbf{W}^{t}$} & \multicolumn{4}{|c|}{ GCN } & \multirow{2}{*}{$\begin{array}{l}\mathbf{P} \\
\hat{0}\end{array}$} & \multirow{2}{*}{$\frac{\mathbf{s}}{0^{\lambda}}$} & \multicolumn{2}{|c|}{ Unsexed small newt } \\
\hline & & & $0^{\lambda}$ & 우 & $\mathrm{J}$ & $\mathrm{L}$ & & & o/ 9 & $\mathrm{~L}$ \\
\hline $23 / 07 / 2016$ & 16.6 & 18.1 & 1 & 5 & 4 & 44 & 9 & 0 & 3 & 0 \\
\hline $14 / 08 / 2016$ & 12.7 & 16.4 & 0 & 0 & 5 & 35 & 1 & 0 & 0 & 9 \\
\hline 02/09/2016 & 12.8 & 16.3 & 0 & 0 & 2 & 38 & 0 & 0 & 1 & 6 \\
\hline 08/10/2016 & 13.9 & 12.4 & 1 & 0 & 0 & 21 & 7 & 0 & 2 & 5 \\
\hline $12 / 11 / 2016$ & 7.2 & 6.7 & 0 & 0 & 0 & 0 & 8 & 0 & 3 & 4 \\
\hline $15 / 12 / 2016$ & 8.6 & 6.9 & 0 & 0 & 0 & 2 & 56 & 0 & 6 & 0 \\
\hline $30 / 01 / 2017$ & 4.5 & 1.9 & 0 & 0 & 0 & 0 & 1 & 0 & 1 & 0 \\
\hline $11 / 02 / 2017$ & 3.5 & 3.7 & 0 & 0 & 0 & 0 & 2 & 0 & 3 & 0 \\
\hline 05/03/2017 & 2.0 & 6.5 & 6 & 0 & 0 & 0 & 5 & 3 & 4 & 0 \\
\hline $11 / 03 / 2017$ & 9.2 & 10 & 15 & 1 & 0 & 0 & 10 & 2 & 14 & 0 \\
\hline $19 / 03 / 2017$ & 7.9 & 9.7 & 1 & 0 & 0 & 0 & 4 & 0 & 2 & 0 \\
\hline 02/04/2017 & 8.8 & 12.9 & 32 & 2 & 0 & 0 & 15 & 0 & 10 & 0 \\
\hline $16 / 04 / 2017$ & 7.7 & 9.6 & 41 & 7 & 0 & 1 & 22 & 4 & 30 & 0 \\
\hline 30/04/2017 & 9.9 & 12.8 & 19 & 0 & 0 & 1 & 2 & 1 & 9 & 0 \\
\hline
\end{tabular}

observed July-September; and larvae were recorded JulyDecember and April.

The highest count of an adult of any confirmed species was palmate male $(n=56)$ on 15 th December $\left(A^{t}=8.6^{\circ} \mathrm{C}\right.$, $\mathrm{W}^{\mathrm{t}}=6.9^{\circ} \mathrm{C}$ ) and the lowest count was a single palmate male recorded on 30th January $\left(A^{t}=4.5^{\circ} \mathrm{C}, W^{t}=1.9^{\circ} \mathrm{C}\right)$. Adult newts were observed in negligible numbers $(\leq 2)$ during counts in August, September and January. On 5th March $\left(A^{t}=2^{\circ} \mathrm{C}, W^{t}\right.$ $=6.5^{\circ} \mathrm{C}$ ) six great crested newts were recorded.

The following incidental records were noted: 15th December, one male palmate observed exhibiting tail fanning behaviour in an open area of the water column, interpreted as a courtship display; 30th January, one male palmate and one unsexed small newt observed swimming in the water column under surface ice (approx. $10 \mathrm{~mm}$ thick); 5th March, one male great crested newt observed in the torchlight before rapidly burying into the silt substrate; and, 19th March, breeding common toad (Bufo bufo) present in relatively high number $(n=57)$ some in amplexus.

\section{DISCUSSION}

Adult male palmate newts were present in the pond during 13 of 14 surveys (Table 1 ), including winter months. The secondary sexual characteristics, which identify these adult males, regress fairly rapidly post-breeding ( $<2$ months), disappearing in the terrestrial environment, and their formation takes 1-2 months upon returning to the aquatic environment (Griffiths \& Mylotte, 1988). Therefore, we can infer that these male newts had likely not recently re-entered the pond after a long period away from the aquatic habitat.

We present strong evidence indicating likely winter residence in an aquatic habitat by a relatively large number of adult male palmate newts at this location. This does not exclude the possibility that newts may have exited the pond for a short period between surveys or entered from an adjacent un-surveyed pond.

Retention of secondary sexual characteristics by newts during winter months does not necessarily imply breeding, as animals might strategically maintain their investment in sexual characteristics for opportunistic mating (IglesiasCarrasco et al., 2016). However, the observation of a male palmate exhibiting tail fanning behaviour on 15th December, although no females were recorded on this date, suggests breeding may occur at this location during winter months. Palmate and smooth newts have been observed elsewhere undertaking early migration (i.e. mid-winter) following milder conditions (Jablonski, 2013); however, based on the developed secondary sexual characteristics, we do not believe the cohort of post-breeding newts exited aquatic habitat for terrestrial hibernacula in winter 2016.

During October-December surveys, male palmate newts were present in considerable numbers, i.e. $\geq 3$ individuals, which on 15th December included the highest adult count $(n=56)$ of any species. This result was quite unexpected as was a sevenfold increase on the previous palmate count from 12th November. Langton et al. (2001) suggest that air temperatures during the days preceding counts may influence the number of active newts in the pond, and our results appear to be in agreement. Specifically, the high count of palmate newts on 15th December was immediately following days with minimum air temperature $13^{\circ} \mathrm{C}$ and $6^{\circ} \mathrm{C}$, recorded at a weather station $9.5 \mathrm{~km}$ east of the pond ('Edinburgh/Gogarbank'; Met Office; www.metoffice.gov. uk/). While this count also appears to indicate that there were more newts present than in summer months, it is 
difficult to compare abundance between seasons as the presence of aquatic vegetation during summer may obscure any newts present, and newts may also be less visible to the surveyor due to behavioural changes when breeding activity ends (Langton et al., 2001). Further, if newts experience temperatures outside of thermal tolerance limits, individuals might bury themselves in the silt; remain in deeper areas of the pond to thermoregulate (Balogová \& Gvoždík, 2015); or exit the pond and therefore be out of view of the surveyor. These behaviours might explain the low count during JanuaryFebruary when air temperatures $<4.5^{\circ} \mathrm{C}$.

Notwithstanding, it seems unlikely that these factors explain the relatively low numbers of adult palmate male recorded during the breeding season surveys in April 2017 (Table 1). It is possible that males may have exited the pond after December 2016 and only recently (<1 month) returned to the pond after hibernating in the terrestrial environment and thus have underdeveloped sexual characteristics. In this scenario, it would be more appropriate to aggregate male and unsexed small newt when comparing the counts from these dates: the total count of $n=52$ palmate newts is closer when compared to the high count of adult male palmate newts on 15th December $(n=56)$.

On 10 of 14 surveys the water temperature was warmer than the air temperature and on 2 nd April we recorded a water temperature which was $4.1^{\circ} \mathrm{C}$ greater than the air temperature (Table 1 ). Given that newts are known to adjust their position in the water column based on water temperature (Balogová \& Gvoždík, 2015), which would affect their visibility, it is clear that water temperature is an important parameter in survey design, as suggested by Paterson (2018). Future research should examine the relationship between newt counts and local environmental parameters with increased temporal resolution, e.g. daily, and duration $>10$ months, to account for inter-annual variations.

There have been few previous reports of large numbers of adult newts in aquatic habitat during winter months. This behaviour is of interest because it is during winter months that conservation activities, for example removal of pond vegetation and substrate material, are undertaken with the aim of improving breeding habitat for newt populations. Our finding indicates that newts may be seriously disturbed or killed during such activities. Presence in ponds during winter alongside any changes in phenology resulting from climate change should be considered in the context of management (Dervo et al., 2016). Given that conservation measures for great crested newt are embedded in statutory legislation, such as the European Union's Conservation (Natural Habitats, \&c.) Regulations 1994, there is clear merit in exploring the occurrence of winter presence in ponds over greater temporal and spatial scales.

\section{ACKNOWLEDGEMENTS}

We thank Rosanna Mooney, Ben Kelly, Elisabeth Ferrell, Rebecca Lilley, and Zeltia Lopez-Gallego for their assistance in collecting the data analysed here. Thanks go to Dr. Jenny McLeish (Edinburgh Napier University) for comments on an early version of the manuscript; and to Nosrat Mirzai (University of Glasgow) for calibration of survey equipment. Comments provided by two reviewers were very helpful in refining the manuscript. Research was carried out with permission from Scottish Natural Heritage.

\section{REFERENCES}

ARG UK. (2014). Amphibian Identification. Available from: https://www.arguk.org/info-advice/id-guides/207amphibian-id-guide-2014-updated/file [Accessed 14th February 2019].

Balogová, M. \& Gvoždík, L. (2015). Can newts cope with the heat? Disparate thermoregulatory strategies of two sympatric species in water. PLOS ONE 10(6): e0130918.

Dodd, J. M. \& Callan, H. G. (1955). Neoteny with Goitre in Triturus helveticus. Quarterly Journal of Microscopial Science 96: 121-128.

Dervo, B. K., Bærum, K. M., Skurdal, J. \& Museth, J. (2016). Effects of Temperature and Precipitation on Breeding Migrations of Amphibian Species in Southeastern Norway. Scientifica 2016: 1-8.

Edgar, P. \& Bird, D. R. (2006). Action Plan for the Conservation of the Crested Newt Triturus cristatus Species Complex in Europe. Council of the European Union, Strasbourg, France. 33 pp.

English Nature. (2001). Great Crested Newt Mitigation Guidelines. Natural England, Peterborough. 75 pp.

Griffiths, R. A. (1984). Seasonal behaviour and intrahabitat movements in an urban population of smooth newts, Triturus vulgaris (Amphibia: Salamandridae). Journal of Zoology, London 203: 241-251.

Griffiths, R. A. \& Mylotte, V. J. (1988). Observations on the development of the secondary sexual characters of male newts, Triturus vulgaris and T. helveticus. Journal of Herpetology 22: 476-480.

Griffiths, R. A., Raper, S. J. \& Brady, L. D. (1996). Evaluation of a standard method for surveying common frogs (Rana temporaria) and newts (Triturus cristatus, T. helveticus and T. vulgaris). JNCC Report No. 259, Joint Nature Conservation Committee, Peterborough. 29 pp.

Griffiths, R. A. (1997). Temporary ponds as amphibian habitats. Aquatic Conservation: Marine and Freshwater Ecosystems 7: 119-126.

Iglesias-Carrasco, M., Head, M.L., Jennions, M.D. \& Cabido, C. (2016). Condition-dependent trade-offs between sexual traits, body condition and immunity: the effect of novel habitats. BMC Evolutionary Biology 16: 135.

Jablonski, D. (2013). Unusual observation of the winter activity of Lissotriton vulgaris from south-western Slovakia. Folia faunistica Slovaca 18: 301-302.

Jehle, R., Orchard, D. \& Barratt, C. (2013). Nativeness of Great Crested Newts (Triturus cristatus) in the Scottish Highlands. Scottish Natural Heritage Commissioned Report No. 570, $18 \mathrm{pp}$.

Langton, T.E.S., Beckett, C.L. \& Foster, J.P. (2001). Great Crested Newt Conservation Handbook. Froglife, Halesworth. 56 pp.

Mclnerny, C. J. \& Minting, P. J. (2016). The Amphibians and 
Reptiles of Scotland. The Glasgow Natural History Society, Glasgow, Scotland. 320 pp.

McNeill, D.C. \& Downie, J.R. (2017). Overwintering of smooth and palmate newt larvae in the Gartcosh Nature Reserve, Scotland. The Glasgow Naturalist 26.

Paterson, E. (2018). Changes in relative population size detection rates of great crested newts (Triturus cristatus) over time. Herpetological Bulletin 143: 12-17.
Van Gelder, J. J. (1973). Ecological observations on amphibia in the Netherlands. II. Triturus helveticus helveticus Razoumowski: migration, hibernation and neoteny. Netherlands Journal of Zoology 23: 86-108.

Verrell, P. \& Halliday, T. (1985). The population dynamics of the crested newt Triturus cristatus at a pond in southern England. Holarctic Ecology 8: 151-156.

Accepted: 6 August 2019 